\title{
PENGUATAN PENDIDIKAN ETIKA ISLAM SEBAGAI PROTEKSI EKOLOGIS
}

\author{
Oleh: Muzamil \\ Dosen Sekolah Tinggi Agama Islam (STAI) \\ Ma'had Aly Al-Hikam Malang \\ Email : muzamilzaini099@gmail.com
}

\begin{abstract}
Abstrak
Tidak sedikit manusia atau bangsa ini yang sudah melakukan tindakan atau menunjukkan perbuatan yang merugikan lingkungan hidupnya. Sumberdaya ekologis dirusaknya sendiri, padahal dalam doktrin edukatif yang mengajarkan etika proteksi ekologis, setiap subyek manusia di muka bumi ini wajib mendidik atau membentukn karakternya yang berbasis perlindungan ekologis, dan bukannya menciptakan banyak dan beragam pola penghancurannya. Penghancuran sumberdaya ekologis identic dengan menghancurkan peradaban.
\end{abstract}

Kata kunci: ekologis, kerusakan, manusia, etika, Islam

\section{Abstract}

Not a few people or this nation who have done an action or show actions that harm the environment. Ecological resources are destroyed by themselves, whereas in the educational doctrine that teaches the ethics of ecological protection, every human subject on earth must educate or form his character based on ecological protection, and not create many and diverse patterns of destruction. Ecological resources destruction is identic by destroying civilization.

Keywords: ecological, damage, human, ethics, Islam

\section{PENDAHULUAN}

"Abite nummi, ego vos mergam, ne mergar a vobis", yang artinya "pergilah wahai uang, saya akan menenggelamkan kamu, sehingga kamu tidak bisa menenggelamkan saya", adalah kata Mutiara yang mengingatkan agar setiiap manusia atau subyek pembangunan dimanapun di dunia ini untuk berhati-hati dengan uang, karena pemujaan (pementingan berlebihan) terhadap uang bisa menghancurkan keberlanjutan hidupnya, dan bahkan terhadap alam semesta ini. ${ }^{1}$ Hal-hal yang berkaitan dengan uang ini diantaranya adalah sumberdaya ekonomi atau bernilai kapitalistik, termasuk

${ }^{1}$ Zuhron Muhdi, Membaca Perkembangan Kejahiliahan Manusia, (Jakarta: vivapres, 2015), 2. 
korporasi yang bisa mendatangkan keuntungan kekayaan yang berlimpah. ${ }^{2}$ Mahatman Gandi pernah menulis "alam ini sangat cukup untuk memenuhi kebutuhan hidup manusia, namun menjadi tidak cukup untuk memenuhi keserakahannya". 3

Di dunia ini, banyak manusia serakah. Saat manusia menunjukkan keserakahan, tidak ada sumberdaya apapun yang dianugerahkan Tuhan yang cukup memenuhinya. Dalam diri manusia ada kecenderungan merasa kurang, yang kekurangannya ini selalu menuntut pemenuhan. Di satu aspek dipenuhi, muncul keinginan lainnya untuk meminta dipenuhi lagi.

Keserakahan manusia di dunia itu secara general tidak mengenal titik akhir. Siapa saja yang memelihara, apalagi berkeinginan terus menerus meghidupkannya, maka segala yang tersedia sebagai sumberdaya yang disediakan Tuhan, ditempatkannya sebagai obyek. Obyek ini ibarat menu makanan yang dipilih dan dimakan, namun tidak pernah membuatnya menjadi kenyang (puas).

Seseorang atau sejumlah orang yang serakah itu dapat terbaca pada individu atau korporasi yang punya banyak uang. Mereka ini bisa menunjukkan keinginan atau ambisinya dengan mengadakan (membangun) suatu bangunan gedung seperti hotel, apartemen, dan lainnya. Gedung ini bisa bermacam-macam sesuai dengan kepentingan yang membangunnya. Masalahnya, apakah manusia atau pemerintah hanya harus membangun tanpa memikirkan kepentingan fundamental lainnya, khususnya dari aspek masa depan masyarakat dan daerah.

\section{PEMBAHASAN}

\section{Sumberdaya Ekologis}

Dalam membangun bangunan gedung itu, ada yang memerlukan lahan yang jumlah atau luasanya banyak. Dari luas dan banyaknya ini dapat diukur dengan tingkat besaran kepentingan atau keuntungannya. Kalangan pemilik modal atau korporasi, tentulah mengalkulasinya berdasarkan nilai keuntungaan yang akan diperolehnya.

Karena penggunaan modal dan keuntungan yang berpijak pada lahan atau tanah itu, maka memang sudah seharusnya kalau setiap rezim lokal seperti pemerintahan daerah, berupaya mengaturnya. Antara pemilik modal dengan kepentingan pembangunan/pendirian bangunan gedung, harus ada aturan main (rule of game) yang berkepastian hukum, di samping mempertimbangkan aspek fundamental lainnya.

\footnotetext{
${ }^{2}$ Ibid.

${ }^{3}$ M. Imam Kb, Agama dalam Semesta Kehidupan Manusia, (Jakarta: Nirmana
} Media, 2007), 54. 
Dalam pembangunan bangunan gedung, yang otomatis membutuhkan tanah atau lahan banyak dan luas, pemerintahan lokal atau daerah wajib menjadi pengatur yang baik supaya para pemilik modal, pengusaha, atau pembangun (pengembang), tetap terkawal atau tidak terbuai semata dalam perburuan mencari keuntungan ekonomi.

Misalnya tentang Rancangan Peraturan Daerah (Ranperda) atau diskresi di beberapa daerah yang membahas tentang Bangunan Gedung, ${ }^{4}$ atau aprtemen, hotel, dan seterusnya memang di satu sisi merupakan norma yuridis yang dibutuhkan, namun di sisi lain, tatanan ini juga wajib dikritisi oleh setiap subyek masyarakat, khususunya dari kalangan agamawan, etika, dan pemerhati masalah lingkungan hidup.

Salah satu aspek yang wajib dikritisi adalah soal kepentingan eksistenial sumberdaya hutan, air, dan sektor strategis lainnya yang mesti terkait dengan pembangunan dari aspek fisik.

Kepentingan seperti itu tidak bisa dianggap ringan oleh siapapun, termasuk oleh Pemerintah Daerah atau kalangan pemodal darimanapun. Mengabaikan sumberdaya strategis ini, ibarat menempatkan suatu kota atau daerah tertentu di nusantara ini dalam bahaya besar, terutama di masa-masa mendatang.

Salah satu kota yang bisa digunakan sebagai bahan refleksi adalah Kota Batu. Di Kota Batu (bagian dari Malang Raya) yang dikenal sebagai kota wisata, kecenderungan membangun/mendirikan bangunan gedung berorientasi mendapatkan atau mendatangkan uang banyak, sangatlah besar. Para pengunjung yang haus hiburan atau rekreasi, sudah terbukti berbondong-bondong ke Kota Batu. Para pemodal yang bisa membaca antusiasme wisatawan mengunjungi Kota Batu, sangat logis jika menggunakan modalnya untuk menyediakan berbagai model bangunan gedung, baik dalam bentuk hotel, resto, cafe, dan lain sebagainya.

Kalau misalnya wilayah/daerah wisata seperti itu secara terus menerus "dieksploitasi" oleh kalangan pemodal untuk mendirikan bangunan gedung, sementara kepentingan fundamentalnya tidak dipertimbangkan eksistensialnya, patut ditakutkan kalau keuntungan ekonomis-pragmatis ini nantinya tidak sebanding dengan tingkat kerugian seperti ancaman atau terjadinya berbagai peristiwa semisal tanah longsor, banjir, kebakaran, dan perubahan suhu yang bersifat radikal.

\section{Manusia sudah dapat Pelajaran}

Berbagai riset menemukan dan sekaligus mengingatkan, bahwa bahaya yang dapat ditimbulkan dari hilangnya sumber mata air yang

4 Pemerintahan Kota Batu, Rancangan Peraturan Daerah Kota Batu tentang Bangunan Gedung, 2015. 
berhubungan dengan alih fungsi lahan dan perusakan hutan. Destruksi hutan yang tidak terkendali, dapat mempercepat terjadinya kehancuran daerah atau wilayah. Masyarakat di daerah bukan hanya akan terus menjadi "langganan" bencana alam, tetapi juga lambat laun bisa menjadi korban massal dan bersifaf eksplosif.

Dalam kasus jatuhnya korban nyawa manusia akibat bencana alam, setidaknya kita bisa belajar dari tragedi Banjarnegara. Dalam tragedi tanah longsor ini, selain puluhan rumah tertimbun tanah, juga puluhan manusia kehilangan hak hidupnya. Mereka kehilangan hak keselamatan dan keberlanjutan hidupnya akibat bencana tanah longsor.

Kepala Pusat Data dan Informasi Badan Nasional Penanggulangan Bencana (BNPB) menyampaikan temuannya tentang beberapa penyebab terjadinya longsor di Dusun Jemblung, Desa Sampang, Kecamatan Karangkobar, Kabupaten Banjarnegara, Jawa Tengah, bahwa pada dua hari menjelang terjadinya longsor, yaitu pada tanggal 10-11 Desember, wilayah di sekitar Dusun Jemblung, Banjarnegara, diguyur hujan yang cukup deras. Akibatnya, tanah di lokasi tersebut menjadi penuh dengan air. Kemudian, di Dusun Jemblung, merupakan endapan vulkanik tua sehingga solum atau lapisan tanah cukup tebal dan terjadi pelapukan, di samping kemiringan lereng di bukit tersebut kurang dari 60 persen. Saat kejadian, mahkota longsor berada pada kemiringan lereng 60-80 persen. Tanaman di atas bukit tempat terjadinya longsor adalah tanaman semusim, dengan jenis palawija, yang tidak rapat. Akibatnya, kondisi tanah menjadi longgar dan mudah terbawa air. Penyebab longsor lainnya adalah tidak lepas dari ulah manusia sendiri, yakni budidaya pertanian yang tidak mengindahkan konservasi juga jadi penyebab. Kondisi tanah dan air di lokasi kejadian, di mana tidak ada terasering pada lereng tersebut. ${ }^{5}$

Sebagai contoh untuk pelajaran bangsa ini, bahwa selama tahun 2014, tercatat terdapat 1.525 kejadian bencana, yang menyebabkan 566 orang tewas, 2,66 juta jiwa mengungsi dan menderita, lebih dari 51 ribu rumah rusak, dan ratusan bangunan umum rusak. Kerugian ekonomi mencapai puluhan trilyunan rupiah. Bencana alam meliputi kebakaran hutan dan lahan, banjir, banjir bandang dan longsor. 99 persen bencana di Indonesia selama 2014 adalah bencana hidrometeorologi. Puting beliung adalah jenis bencana yang paling dominan selama 2014 yaitu 496 kejadian, kemudian banjir (458) dan longsor (413). Walaupun puting beliung adalah bencana yang paling banyak terjadi selama 2012-2014, namun longsor adalah bencana paling mematikan. Pada tahun 2014, 60 persen (343 jiwa) dari dari total korban meninggal akibat bencana adalah

\footnotetext{
${ }^{5}$ Lukman Hakim, Belajar dari Bencana ke Bencana, Makalah, Surabaya, 2015, 2.
} 
disebabkan longsor. Konsentrasi bencana terbanyak adalah di Provinsi Jawa Barat (290 kejadian), Jawa Tengah (272), Jawa Timur (213), Aceh (51), dan Sumatera Selatan (480). Dilihat dari sebaran kab/kota, maka paling banyak ada di Bogor (37), Bandung (31), Sukabumi (29), Garut (26), dan Cianjur (23). ${ }^{6}$

Kasus tragedi bencana alam sepanjang tahun 2014 itu seharusnya mencerdaskan atau menyadarkan kita, bahwa tragedi semacam itu dan bahkan lebih berskala makro bisa terjadi dimana saja, termasuk di Kota Batu. Tidak ada suatu kawasan yang terbebas dari bencana alam yang berdampak mengerikan di negeri ini, bilamana perilaku manusia memang secara langsung atau tidak langsung "memotivasi" atau menjadi akar penyebab terjadinya bencana.

Di samping itu, ancaman atau bahaya yang berhubungan dengan nyawa manusia itu, juga adanya ancaman terhadap eksistensi sumberdaya air dan keberlanjutan sumberdaya strategis ekologis lainnya. Sudah banyak contoh keterancaman sumber mata air akibat perusakan hutan atau pengalihan fungsi hutan.

Diberitakan, bahwa puluhan mata air di kawasan hulu Sungai Brantas mati. Sebagian lainnya terus mengalami pengecilan debit. Dalam kurun dua tahun terakhir, sebelas mata air mengering. Adapun debit 46 mata air yang masih ada makin menyusut, dari semula 10 menjadi 5 meter kubik per detik. Masyarakat melakukan reboisasi dan berbagai usaha lain untuk menjaga kelestarian mata air itu. Pada 2007, ada 170 mata air di hulu Sungai Brang. Namun, hanya dalam rentang waktu setahun kemudian, jumlahnya turun menjadi 111. Pada 2009, tersisa 46. Dari total sumber air di Kota Batu, 30 persen berada di Kecamatan Bumiaji. Namun belakangan debit mata air itu terus menyusut, termasuk sumber air Sungai Brantas, yang mengaliri 14 kota dan kabupaten di Jawa Timur. ${ }^{7}$

Selama ini, Kawasan Kota Batu menjadi salah satu kunci pelestarian sumber air karena berada di lereng Gunung Arjuna dan Anjasmara. Data Dinas Pengairan Provinsi Jawa Timur 2010 mencatat Jawa Timur mempunyai 4.389 mata air yang tersebar di 30 kabupaten. Dari jumlah tersebut, 109 di antaranya berada di Batu. Namun, debit mata air di sana terus menyusut dari tahun ke tahun. ${ }^{8}$. Penyusutan air ini tidak lepas dari perilaku manusia yang gagal mengendalikan hasrat besarnya.

Sejalan dengan itu, Direktur Eksekutif Walhi Jawa Timur, Ony Mahardika (2014) membenarkan, bahaya krisis air akibat alih fungsi lahan tidak hanya berbahaya bagi manusia, melainkan juga dapat menyebabkan

\footnotetext{
${ }^{6}$ Zuhron Muhdi, Op.Cit, 5.

${ }^{7}$ Tempo, 7 November 2014, akses 6 Januari 2018.

${ }^{8}$ Ibid.
} 
bencana ekologi yang lebih besar. Kalau membaca kerusakan di hulu sungai Brantas, pertama karena alih fiungsi lahan dimana hutan lindung dijadikan industri pertanian ekstraktif, serta bangunan hotel atau villa yang dibangun diatas sumber matra air. ${ }^{9}$

Kasus itu menunjukkan, bahwa bencana yang berelasi dengan destruksi ekologi yang akan dialami masyarakat Jawa Timur bisa terjadi dengan menggerikan. Masyarakat yang sedang tertidur lelap atau berenang di kolam renang atau menikmati liburan di sekitar alam pegunungan, bisa dengan tiba-tiba digulung oleh banjir bandang atau tanah longsor.

Selain itu, ancaman krisis air, termasuk di Batu, yang diperkirakan Sekjen PBB akan terjadi pada 2025, sebagian besar disebabkan oleh alih fungsi lahan serta pembangunan di kawasan hutan lindung. Misalnya data yang dimiliki Walhi Jawa Timur menyebutkan, jumlah sumber mata air di hulu sungai Brantas (termasuk Kota Batu) sebelun 2005 berjumlah 421 tempat, pada 2005 terdapat 221 lokasi, 2009 tinggal 57 titik, dan pada 2012 menyisakan 13 sumber mata air. ${ }^{10}$

Dalam ranah berfikir, adalah logis jika masyarakat sejak lama menolak pendirian bangunan gedung di atas sumber air atau menggunakan lahan atau kawasan hutan yang menjadi titik-titik mata air, sebab pendirian atau pembanan demikian bukan hanya akan potensial mereduksi dan mendegradasi keberlanjutan hidup sumberdaya air untuk masyarakat dan kepentingan lainnya, tetapi juga rentan mengundang dan memperluas terjadinya bencana alam.

Memang masih saja ditemukan seseorang atau sekelompok orang dan korporasi yang berkeinginan atau berambisi besar untuk mengembangkan aktifitas membangun/mendirikan bangunan gedung guna mendatangkan keuntungan ekonomi besar tanpa mengindahkan kepentingan sumberdaya ekologis. Hal inilah yang pernah diingatkan oleh filosof Aristoteles, bahwa semakin tinggi penghargaan manusia terhadap kekayaan, maka semakin rendahlah penghargaan manusia terhadap nilai-nilai kemanusiaan, kebenaran, kepatutan, dan keadilan. ${ }^{11}$ Pernyataan filosof ini mengingatkan dengan keras tentang bahayanya manusia atau subyek pembangunan yang hanya mengutamakan kepentingan ekonomi.

Membangun/mendirikan bangunan gedung memang merupakan kebutuhan atau kepentingan kalangan pemodal dalam mengembangkan usaha-usahanya dan kepentingan pemerintah daerah untuk menggali dan mengembangkan pendapatan asli daerah (PAD), namun "hasrat besar" Ini

${ }^{9}$ Lukman hakim, Op.Cit, 3.

${ }^{10} \mathrm{Ibid}, 3-4$.

11 Abdul Wahid, Mariyadi, Sunardi, Penegakan Kode Etik Profesi Notaris, (Jakarta: Nirmana Media, 2017), 56. 
harus dikendalikan. Salah satu alat yang bisa digunakan untuk mengendalikannya adalah norma yuridis (Peraturan Daerah).

Hal itu sejalan dengan temuan Walhi. Batu dan Pujon misalnya disebut oleh Walhi sebagai daetah yang sangat rawan tanah longsir akibat alih fungsi lahan yang membabi buta. Longsor merupakan konsekuensi logis banjir atau kestabilan tanah menurun. Dalam kasus ini, Walhi mendesak pemerintah daerah untuk meminjau kembali model tata ruang wilayahnya. Salah satunya dengan memperhatikan kawasan-kawasan strategis ekologi, di samping membuat Perda yang benar-benar ditegakkan.

Ranperda atau tatanan pemerintah daerah tentang bangunan gedung memang bisa jadi intrumen mengendalikan hasrat pembangunan bangunan gedung tanpa mempertimbangkan aspek fundamental ekologis, namun jika "celah-celah" masih tersedia bagi kalangan pemodal atau korporasi perumahan, perhotelan, dan lainnya untuk terus mengembangkan sayap kepentingannya secara liberal, maka sulit mencegah kawasan suatu wilayah Kota dan sekitarnya dari terjadinya dan mengeksplosinya bencana alam. Karena aspek keserakahaan akan membuat pembangunan kehilangan "hati nurani”.

Produk tatanan negara atau pemerintah daerah seperti itu, jika nantinya sudah lolos uji publik atau sudah "direvisi" di beberapa pasal atau ayat-ayatnya yang memang masih membutuhkan kajian mendasar, yang kemudian disahkan menjadi norma yang berlaku, maka barulah dapat digunakan sebagai payung yuridis untuk melindungi kepentingan sumberdaya ekologis dari kerusakan dan kehancuran akibat pembangunan/pendirian bangunan gedung.

Filosof kenamaan Franz Magnis Suseno menyatakan, bahwa secara moral politik setidaknya ada empat alasan utama orang menuntut agar negara diselenggarakan (dijalankan) berdasarkan atas hukum yaitu: pertama, kepastian hukum, kedua, tuntutan perlakuan yang sama, ketiga, legitimasi demokrasi, dan keempat, tuntutan akal budi Hal ini menunjukkan, bahwa setiap masyarakat atau negara atau daerah, harus mempunyai garis pijakan yang berkepastian hukum untuk mengawal perjalanan hidupnya. ${ }^{12}$

Pemikiran itu mengajarkan, bahwa norma yuridis idealisasinya tidak asal diproduk, tetapi benar-benar digodok yang nantinya diidealitaskan mampu memberikan kepastian, keadilan, dan kemanfatan, yang di dalamnya mengedepankan soal "etik", termasuk memerintahkan adanya langkah preventif edukatif terhadap masyarakat.

Begitu rancangan norma dibuat, misalnya dalam hal ini rancangan aturan tentang bangunan gedung, maka setiap elemen masyarakat

\footnotetext{
${ }^{12}$ Abdul Wahid, Kearifan Bernegara, (Surabaya: Mahirsindo, 2010), 76.
} 
mempunyai kewajiban untuk mengkritisinya. Soal pasal atau ketentuan yang mengatur pembangunan/pendirian bangunan gedung di atas tanah yang rentan bencana banjir, tanah longsor, dan lainnya, atau pasal yang mengatur soal bangunan gedung berlantai 8 (delapan) lebih, atau bangunan gedung di atas sumber mata air, rakyat harus terus mengawalnya.

Misalnya ketika kedepan disahkan atau dinyatakan berlaku sebagai produk hukum daerah untuk masyarakat Kota Batu, maka setiap elemen masyarakat berkewajiban mengawalnya. Ditakutkan jika tidak sampai dikawal atau terus dicermati dengan kritisi oleh masyarakat, norma yang diproduk ini, bukan hanya dapat kehilangan daya berlakunya untuk mengawal jalannya pembangunan, dalam hal ini pembangunan/pendirian bangunan gedung, tetapi juga dijadikan instrumen untuk memenuhi kepentingan beberapa $g$ elintir orang.

Tatanan (hukum negara) seperti itu dibuat sebagai wujud responsi kepentingan riil, empirik, dan obyektif masyarakat. Tatanan ini dibuat bukan sekedar supaya ada norma yuridis, tetapi bagaimana kepentingan besar masyarakat, seperti kepentingan membangun/mendirikan bangunan gedung mempunyai regulasi yang benar, sementara kepentingan pembangunan atau proteksi ekologis sekarang dan mendatang, benar-benar terjaga.

Salah satu tolok ukur keberhasilan suatu pembangunan di daerah adalah terlaksana atau terkawalnya proyek-proyek yang sudah digariskan oleh pemda atau terwujudnya regulasi atau kebijakan yang berbasis pembebasan masyarakat dari berbagai bentuk ancaman yang menyengsarakan, menghilangkan keberdayaan, dan menghancurkan hakhak publiknya.

Deskripsi itu menunjukkan, bahwa kesuksesan pembangunan di daerah ditentukah oleh terjadinya perubahan dalam kehidupan kemasyarakatan. Sedangkan instrumen yang bisa digunakan untuk melakukan perubahan adalah norma yuridis yang dibuat negara atau pemerintah.

Ketika produk yuridis tentang pengaturan bangunan gedung mampu dilaksanakan dan dikawal atau dikontrol, maka setidaknya masyarakat bisa dibebaskan dari kondisi yang potensial menghancurkan dan menyusahkan. Bencana alam merupakan salah satu kondisi yang menyengsarakan, yang bisa mengandalkan norma hukum untuk mencegah atau menanggulanginya. Apakah hanya norma yuridis saja yang bisa digunakan mebcegah bencana? Bagaimana dengan norma agama? 


\section{Perspektif Pendidikan Etika Islam}

Banyak pakar yang mengkritisi hubungan manusia dengan etika. Manusia meang disebut sebagai pelaku yang menentukan perubahan, akan tetapi juga bisa menghancurkan peradaban. Ilmuwan Kenamaan Baqir AlSadr menyatakan, bahwa manusia adalah pelaku yang menciptakan sejarah. Gerak sejarah adalah gerak menuju suatu tujuan. Tujuan tersebut berada di hadapan manusia: yakni berada "di masa depan.",13

Pernyataan tersebut menunjukkan, bahwa memikirkan dan merancang masa depan suatu wilayah/daerah, apa itu di pedesaan atau perkotaan jelas berada di tangan manusia, di tangan setiap elemen bangsa, atau dalam kekuatan masyarakat. Bagaimana wajah masyarakat atau bangsa Indonesia di masa depan, sangat ditentukan oleh kemampuan manusiamanusia dalam merancangnya sejak sekarang. Manusia adalah penentu disain kehidupannya sekarang dan untuk keberlanjutan hidup generasi di hari esok. ${ }^{14}$

Produk tatanan negara atau diskresi pemerintah daerah tentang perluasan pembangunan seperti hotel, apartemen, dan seterusnya yang misalnya sedang menjadi pembahasan di sejumlah pemerintahan daerah memang dibutuhkan kehadirannya, namun demikian dalam tatanan negara atau diskresi demikian ini, rancangan masa depan suatu wilayah atau kota ditentukan, jika substansinya tidak memedulikan kepentingan pembangunan ekologis. Kalau ingin membangun yang pembangunannya ini bisa dirasakan rakyat secara keseluruhan, maka janganlah kepentingan fundamental rakyat dikorbankan.

Para pemodal di seluruh negeri ini wajib kita ajak berjalan di jalur yang benar, bertanggungjawab, dan sesuai dengan norma yuridis/tatanan negara atau diskresi yang aspiratif dengan masa depan masyarakat. Artinya hal demikian harus dikembalikan manfaatnya kepada masyarakat, apakah menjadi produk ideal yang merupakan perwujudan aspirasi atau kepentingan riil masyarakat, ataukah tidak.

Karena tatanan negara atau diskresi itu berurusan dengan masalah sumberdaya ekologis, maka yang harus menjadi fokus utama tatanan negara atau diskresi, adalah perlindugan sumberdaya ekologis. Kalau hal ini tidak menjadi fokus perhatian, tentu saja berbagai bentuk akibat serius seperti bencana alam, akan menjadi ancaman utama bagi masyarakat sekarang dan masa mendatang.

Dalam ranah kesejatiannya, eksistensi Islam adalah mengajarkan pada umatnya untuk menyayangi binatang dan melestarikan kehidupannya.

\footnotetext{
${ }^{13}$ Ahmad Sonhaji, Resiko Kegagalan Manusia sebagai Khalifah di Muka Bumi, (Surabaya: Titian Pres, 2013), 2.

${ }^{14}$ Zuhron Muhdi, Op.Cit, 3.
} 
Menyayangi dalam konsep ini identik dengan konsep edukatif etik, artinya manusia harus mengedukasikan dirinya atau segala perilakunya yang berkecenderungan merusak supaya menjadi perilaku yang melindungi/menyayangi. Pendidikan etika ini bermaknakan aktualisasi pengedukasian diri dari kecenderungan melakukan pengabaian atau peruskan sumberdaya ekologis.

Di dalam Al-qur'an, Allah SWT menekankan bahwa telah menganugerahi manusia wilayah kekuasaan yang mencakup segala sesuatu didunia ini, hal ini tertuang dalam surat Al-Jatsiyah,45:13 yang artinya sebagai berikut: "Dan Dia telah menundukan untukmu segala apa yang ada di langit dan segala apa yang ada di muka bumi; semuanya itu dari Dia; sesungguhny di dalam yang demikian itu terdapat tanda-tanda bagi orangorang yang berfikir (Q.S. Al-Jatsiyah,45:13). ${ }^{15}$

Ayat tersebut juga sama sekali tidak menunjukan bahwa manusia memiliki kekuasaan mutlak (carte blance) untuk berbuat sekendak hatinya dan tidak pula memiliki hak tanpa batas untuk menggunakan alam sehingga merusak keseimbangan ekologisnya. Begitu pula ayat ini tidak mendukung manusia untuk menyalahgunakan binatang untuk tujuan olahraga maupun untuk menjadikan binatang sebagai objek eksperimen yang sembarangan. Ayat ini mengingatkan umat manusia bahwa Sang Pencipta telah menjadikan semua yang ada di alam ini (termasuk satwa) sebagai amanah yang harus mereka jaga. ${ }^{16}$ Dengan kata lain, etika harus menjadi perhatian manusia dalam menjalani aktifitasnya, baik yang berhubungan dengan sesama manusia maupun dengna lingkungan hidupnya. Manusia terlarang mengutamakan pemenuhan kebutuhan ekonomi dengan mengabaikan perlindungan sumberdaya ekologis.

Perlindungan dan pengelolaan alam dan sumberdaya alam (bumi seisinya) merupakan ketentuan (sunnatullah) sekaligus perintah Allah. Oleh karena itu wajib secara moral bagi semua orang untuk melaksanakannya. Upaya perlindungan dan konservasi sumberdaya alam sama dengan upaya menjaga keberlangsungan kehidupan seluruh makhluk, termasuk kehidupan manusia. Menjaga alam dari kerusakan untuk keberlanjutan fungsi alam serta memakmurkan bumi merupakan penunaian amanah yang telah diberikan oleh Allah kepada manusia sebagai wakil (khalifah) Tuhan di muka bumi. Akhlak seseorang terhadap alam lingkungan hidupnya merupakan cermin keberagamaan dan keimanan orang yang bersangkutan

\footnotetext{
${ }^{15}$ Fachruddin Mangunjaya, Perlindungan Satwa dalam Pandangan Islam, http://agamadanekologi.blogspot.com/2007/08/perlindungan-satwa-dalam-pandangan.html, akses 15 Januari 2019.

${ }^{16} \mathrm{Ibid}$.
} 
kepada Allah. ${ }^{17}$ Tuntutan memproteksi sumberdaya ekologis ini identik dengan menuntut setiap individu manusia untuk mengedukasikan atau mendidik dirinya secara etis supaya tidak menjadi "manusia-manusia yang jahiliyah" atau manusia yang sebenarnya pintar, tapi pandir dengan kemaslahatan ekologisnya. ${ }^{18}$

Permasalahan lingkungan dan perlindungan alam dan sumberdaya alam tak bisa diselesaikan hanya dengan mengandalkan pengetahuan dan teknologi. Permasalahan dan krisis lingkungan hanya bisa diatasi dengan merubah secara fundamental dan radikal cara pandang dan perilaku manusia terhadap alam lingkungannya. Dengan kata lain dibutuhkan perubahan pemahaman baru tentang hubungan antara manusia dengan alam. Teologi hubungan manusia dengan alam yang merupakan konsep berpikir dan bertindak manusia yang dihubungkan dengan "Yang Ghoib" yang menciptakan sekaligus mengatur alam harus digunakan untuk melandasi perilaku manusia terhadap alam. Dalam kalimat lain: Ajaran agama (Islam) harus dilibatkan bahkan digunakan sebagai basis dalam upaya perlindungan dan pengelolaan lingkungan. ${ }^{19}$

Al-qur'an berkali-kali mengingatkan bahwa kelak manusia akan mempertanggungjawabkan semua perbuatan mereka di dunia, seperti yang termaktub dalam ayat berikut: "barang siapa melakukan amal saleh, maka (keuntungannya) adalah untuk dirinya sendiri; dan barang siapa melakukan perbuatan buruk, maka itu akan mengenai dirinya sendiri. Dan kelak kamu semua akan kembali kepada Tuhanmu" (Q.S Al-Jatsiyah, 45:15). ${ }^{20}$

Berpijak pada sumber wahyu Allah tersebut, umat manusia memang diperbolehkan memanfaatkan sumberdaya ekologis, namun dalam pemanfaatannya ini sekaligus diberi kewajiban memberikan perlindungan demi keberlanjutan hidupnya.

Muhammad Fazlur Rahman Anshari mengingatkan juga: bahwa segala yang dimuka bumi ini diciptakan untuk kita, maka sudah menjadi kewajiban alamiah kita untuk menjaga segala sesuatu dari kerusakan, memanfaatkannya dengan tetap menjaga martabatnya sebagai ciptaan Tuhan; melestarikannya secara maksimal (sebisa mungkin), yang dengan demikian, mensyukuri nikmat Tuhan dalam bentuk perbuatan nyata

${ }^{17}$ Muhjiddin Mawardi, Perlindungan dan Pengelolaan Lingkungan Berbasis Agama, http://muhammadiyahgoesgreen.blogspot.com/2011/09/perlindungan-danpengelolaan-lingkungan.html, akses 15 Januari 2019.

${ }^{18}$ Zuhron Muhdi, Op.Cit, 6.

${ }^{19}$ Muhjiddin Mawardi, Op.Cit,

${ }^{20}$ Fachruddin Mangunjaya,. Op.Cit. 
(empirik). ${ }^{21}$ Kewajiban menjaga ini identik dengan mengedepankan dimensi etika sebagai kekuatan moral untuk menjaga lingkungan hidup. Mendidik diri secara etik ekologis sama dengan penguatan proteksi masa depan peradaban manusia juga.

\section{PENUTUP}

Pemerintah pusat hingga derah banyak mengeluakan kebijakan atau tatanan yang berkaitan dengan kepenetingan pembangunan, yang terkadang lebih mementingkan pengejaran aspek ekonomi dengan mengabaikan sisi proteksi ekologisnya. Salah satu produk kebijakan di daerah misalnya yang digunakan mengatur masyarakat berkaitan dengan bangunan gedung atau bagaimana masyarakat elit, khususnya kalangan pemilik modal atau pengusaha membangun bangunan yang digunakan mengembangkan bisnis atau bangunan gedung ini dijadikannya sebagai obyek bisnis, yang kepentingannya ini kurang atau tidak memedulikan perlindungan ekologis.

Karena pembangunan itu berhubungan dengan masalah sumberdaya ekologis, maka model pembangunan yang benar, idealitasnya haruslah yang berbasis proteksi atau perlindungan ekologis. Perlindungan ekologis inilah yang sangat ditekankan oleh ajaran etika Islam. Dalam doktrin Islam, manusia berkewajiban mendidik dirinya melakukan perlindungan sumberdaya ekologis dimanapun manusia tinggal dan menjalankan aktifitasnya supaya konstruksi pembangunan di masa depan tetap estabilitas dan menyelamatkan peradabannya.

\section{Buku}

\section{DAFTAR PUSTAKA}

Abdul Wahid, 2010, Kearifan Bernegara, Surabaya: Mahirsindo.

Abdul Wahid, Mariyadi, Sunardi, 2017, Penegakan Kode Etik Profesi Notaris, Jakarta: Nirmana Media.

Ahmad Sonhaji, 2013, Resiko Kegagalan Manusia sebagai Khalifah di Muka Bumi, Surabaya: Titian Pres.

M. Imam Kb, 2007, Agama dalam Semesta Kehidupan Manusia, Jakarta: Nirmana Media.

Zuhron Muhdi, 2015 Membaca Perkembangan Kejahiliahan Manusia, Jakarta: vivapres.

${ }^{21}$ Muhammad Fazlur Rahman Anshari, The Qur'anic Founation and Structure of Muslim Society, Karachi: Trade and Industry Publications Ltd, 1973, Vol 2, 126. 


\section{Makalah, Raperda dan Jurnal}

Lukman Hakim, 2015, Belajar dari Bencana ke Bencana, Makalah, Surabaya.

Muhammad Fazlur Rahman Anshari, 1973, The Qur'anic Founation and Structure of Muslim Society, Karachi: Trade and Industry Publications Ltd, 1973, Vol 2.

Pemerintahan Kota Batu, Rancangan Peraturan Daerah Kota Batu tentang Bangunan Gedung, 2015.

\section{Internet}

Fachruddin Mangunjaya, Perlindungan Satwa dalam Pandangan Islam, http://agamadanekologi.blogspot.com/2007/08/perlindungan-satwadalam-pandangan.html, akses 15 Januari 2019

Muhjiddin Mawardi, Perlindungan dan Pengelolaan Lingkungan Berbasis Agama, http://muhammadiyahgoesgreen.blogspot.com/2011/09/perlindunga n-dan-pengelolaan-lingkungan.html, akses 15 Januari 2019.

Tempo, 7 November 2014, akses 6 Januari 2019. 